\title{
Clinical Evaluation of Medetomidine, a Novel Sedative and Analgesic Drug for Dogs and Cats
}

\author{
By Tapani Vähä-Vahe \\ The Research Center, Farmos Group Ltd, Turku, Finland.
}

\begin{abstract}
Vähä-Vahe, T.: Clinical evaluation of medetomidine, a novel sedative and analgesic drug for dogs and cats. Acta vet. scand. 1989, 30, 267-273. - Medetomidine, a potent $\alpha_{2}$-adrenoceptor agonist, was investigated in open, multicenter clinical trials with patients of various canine and feline breeds (1736 dogs and 678 cats). The purpose of the study was to find an optimal dose of medetomidine for sedation and analgesia in clinical practice and to study how well the intended procedure could be performed under the influence of the drug.

The mean dose (i.m.) of medetomidine used for examinations, clinical procedures and minor surgical interventions was $40 \mu \mathrm{g} / \mathrm{kg}$, and for radiography $30 \mu \mathrm{g} / \mathrm{kg}$. In cats the dose was $80-110 \mu \mathrm{g} / \mathrm{kg}$. On the doses chosen, almost all animals were recumbent and $72 \%$ of the dogs and $85 \%$ of the cats were in a slight anaesthetic stage, unable to rise. The evaluation of the overall suitability of medetomidine ( $\%$ of cases) in different indications was "very satisfactory « or "satisfactory « in $95 \%$ of dogs and $81-96 \%$ of cats.

Side effects reported were limited almost exclusively to vomiting and muscle jerking in dogs ( $12 \%$ and $0.5 \%$ of the cases) and to vomiting in cats $(65 \%)$. Medetomidine seems to suffice for pharmacological restraint of dogs and cats. The concomitant use of medetomidine $(80-100 \mu \mathrm{g} / \mathrm{kg})$ and ketamine $(7 \mathrm{mg} / \mathrm{kg})$ in cats $(n=295)$ provided a good anaesthesia $(20-40 \mathrm{~min})$. The recovery was smooth.

The present study shows that medetomidine provides an effective level of sedation and analgesia for clinical use.
\end{abstract}

sedation; analgesia; chemical restraint; ketamine.

\section{Introduction}

Pharmacological restraint, i.e. deep sedation as well as analgesia, has become increasingly necessary in veterinary practice $(\mathrm{Me}$ lby 1985). In small animal practice, xylazine (Moye et al. 1973, Newkirk \& Miles 1974) and acepromazine alone or in combinations (Taylor \& Herrtage 1986) are today most widely used in dogs and cats for this purpose. Medetomidine, 4-[1-(2,3-dimethyl-phenyl) ethyl]-1H-imidazole (Karjalainen 1981) is a selective and potent $\alpha_{2}$-adrenoceptor agonist (Savola et al. 1986, Virtanen et al. 1988). Medetomidine has been shown to induce se- dation and analgesia in laboratory animals and after high doses hypnotic or even anaesthetic properties (Savola et al. 1986, Virtanen 1985).

In laboratory dogs, parenterally administered medetomidine (i.m. or i.v.) in doses ranging from 10 to $180 \mu \mathrm{g} / \mathrm{kg}$ provided sufficient sedation and analgesia for clinical use (Vainio et al. 1989). Stenberg et al. (1987) demonstrated the sedative effect of medetomidine in experimental cats at doses 20, 60 and $180 \mu \mathrm{g} / \mathrm{kg} \mathrm{BW}$.

The purpose of this investigation was to find an optimal dose of medetomidine for seda- 
tion and analgesia in open clinical trials with patients of various canine and feline breeds and to study how well the intended procedure could be performed under the influence of medetomidine.

\section{Material and methods}

Clinical cases from seven small animal clinics were used in the study: a total of 1736 dogs and 678 cats of both sexes. The number of animals, average age and weight are shown in Table 1.

From each of the following breeds, more than 20 individuals were seen in the course of these studies: German Shephard dog, Labrador and Golden Retriever, Cocker Spaniel, Rottweiler, Boxer, Bernese Mountain dog, English Springer Spaniel and Finnish hound. A total of 129 different breeds was seen in the study.

The study was conducted in 2 parts, phase I and II (open clinical trials). The co-operating clinicians were asked to choose the dose of medetomidine for various clinical procedures whenever sedation was needed. The recommended dose range for dogs was 10-100 $\mu \mathrm{g} / \mathrm{kg}$ in phase $\mathrm{I}$ and $10-80 \mu \mathrm{g} / \mathrm{kg}$ in phase II, and for cats $50-150 \mu \mathrm{g} / \mathrm{kg}$ in both phases. The clinical status of the animals before sedation was recorded on individual case report forms. The indications in which medetomidine was used were grouped into: examinations; clinical procedures or minor surgical interventions. Pregnant or visibly diseased animals were excluded. Other seda- tive or analgesic drugs were not given in conjunction with medetomidine except in cats where ketamine $(7 \mathrm{mg} / \mathrm{kg}$ ) was used simultaneously (i.m.) with it (medetomidine 80-100 $\mu \mathrm{g} / \mathrm{kg}$ ), for induction of anesthesia in 295 cases of minor surgery.

In phase I of the study the following observations were made during maximal drug effect:

1. Posture of the animal: standing; recumbent, but able to get up easily; recumbent, but able to get up, although with difficulty, or recumbent and unable to rise.

2. Reaction to sounds: normal, weak or no reaction.

3. Duration of sedation.

4. Reaction to pin prick at the distal part of the limbs (with owner's consent only): normal or weak response; no reaction.

5. Heart rate was measured with stethoscope.

Based on their observations, the investigators were asked to make the following subjective evaluations of the effectiveness of medetomidine:

1. Degree of sedation: "None" = intended procedure could not be performed; the animal remained standing or was able to rise easily; "Slight « = intended procedure could be performed with some difficulty; the dog was recumbent but able to rise, although with difficulty; "Moderate" = intended procedure could be performed with little re-

Table 1. Number, age and weight of dogs and cats.

\begin{tabular}{lccccc}
\hline & \multicolumn{2}{c}{ Dog } & & \multicolumn{2}{c}{ Cat } \\
\cline { 2 - 3 } \cline { 5 - 6 } & Phase I & Phase II & & Phase I & Phase II \\
\hline Number of animals & 533 & 1202 & & 120 & 467 \\
Age range (years) & $0.2-16$ & $0.1-15$ & & $0.3-13$ & $0.3-19$ \\
(mean) & $(4.4)$ & $(4.6)$ & & $(2.1)$ & $(2.9)$ \\
Weight range (kg) & $1-80$ & $1-75$ & & $2-7$ & $1.5-10$ \\
(mean) & $(24.5)$ & $(24.2)$ & & $(3.9)$ & $(3.7)$ \\
\hline
\end{tabular}


sistance; the dog was not able to rise; or "Good" = intended procedure could be performed without resistance; the dog was unable to rise.

2. Degree of analgesia: $"$ None $"=$ strong reaction to painful procedures or to pin pricks; "Slight $"=$ moderate reaction; »Moderate $"$ = only slight reaction; or »Strong" $=$ no reaction to painful procedures or to pin pricks.

3. The overall suitability of medetomidine on the chosen dose for the intended procedures was ranked as: "Very satisfactory « = intended procedure could be performed easily; "Satisfactory " = procedure could be performed without other restraint methods, and the dog was resisting only slightly; or "Unsatisfactory $"=$ intended procedure could not be performed without a restraining method.

In phase II of the study the clinicians were asked to evaluate only the overall suitability of medetomidine on the dose chosen for the procedure with the response: "Very satisfac- tory«, "Satisfactory« or »Unsatisfactory« (for explanation see above).

Side effects were recorded in both phases of the study. To avoid bias, the investigators were not informed about expected side effects.

Medetomidine was provided in $1.5 \mathrm{mg} / \mathrm{ml}$ (phase I) and $1.0 \mathrm{mg} / \mathrm{ml}$ solutions (phase II), prepared for these investigations by Farmos Group Ltd. The preparations were analyzed before and after these trials to ensure that the concentrations had been maintained.

\section{Results}

It was shown in these open clinical trials that medetomidine is able to produce a reliable state of sedation, relaxation and recumbency, which is adequate for performing most of the routine procedures in clinical practice. Table 2 shows that in dogs the mean dose of medetomidine used for examinations, clinical procedures and minor surgical interventions was about $40 \mu \mathrm{g} / \mathrm{kg}$, and for radio-

Table 2. The dose $(\mu \mathrm{g} / \mathrm{kg} \mathrm{BW})$ of medetomidine by indication and weight group. Means $\pm S D$ are given (number of cases in brackets).

\begin{tabular}{|c|c|c|c|c|}
\hline & \multicolumn{2}{|c|}{ Dog } & \multicolumn{2}{|c|}{ Cat } \\
\hline & \multicolumn{2}{|c|}{ Phase } & \multicolumn{2}{|c|}{ Phase } \\
\hline & I & II & I & II \\
\hline $\begin{array}{l}\text { Indications: } \\
\text { Examinations } \\
\text { and clinical } \\
\text { procedures }\end{array}$ & $\begin{array}{c}43.5 \pm 15.7 \\
(204)\end{array}$ & $\begin{array}{c}40.0 \pm 10.1 \\
(515)\end{array}$ & $\begin{array}{c}87.0 \pm 37.7 \\
\text { (21) }\end{array}$ & $\begin{array}{l}83.5 \pm 24.5 \\
\text { (144) }\end{array}$ \\
\hline Minor surgery & $\begin{array}{c}48.0 \pm 15.3 \\
(98)\end{array}$ & $\begin{array}{c}37.5 \pm 12.5 \\
(198)\end{array}$ & $\begin{array}{c}106.0 \pm 19.8 \\
(59)\end{array}$ & $\begin{array}{c}114.0 \pm 13.0 \\
\text { (53) }\end{array}$ \\
\hline Radiography & $\begin{array}{c}33.0 \pm 11.8 \\
(231)\end{array}$ & $\begin{array}{c}30.0 \pm 11.5 \\
(489)\end{array}$ & $\begin{array}{c}108.0 \pm 36.6 \\
(6)\end{array}$ & $\begin{array}{l}83.5 \pm 19.0 \\
\text { (9) }\end{array}$ \\
\hline $\begin{array}{l}\text { Weight: } \\
1-5 \mathrm{~kg}\end{array}$ & $38.3 \pm 13.4$ & $34.7 \pm 13.6$ & & \\
\hline $6-10 \mathrm{~kg}$ & $44.1 \pm 16.1$ & $38.2 \pm 12.6$ & & \\
\hline $11-20 \mathrm{~kg}$ & $40.6 \pm 15.9$ & $37.7 \pm 11.3$ & & \\
\hline $21-30 \mathrm{~kg}$ & $37.9 \pm 13.1$ & $33.9 \pm 12.1$ & & \\
\hline $30-\mathrm{kg}$ & $40.4 \pm 16.8$ & $34.1 \pm 11.8$ & & \\
\hline
\end{tabular}


graphy $30 \mu \mathrm{g} / \mathrm{kg}$. In cats the dose was clearly higher $(80-110 \mu \mathrm{g} / \mathrm{kg})$. The preferred route of administration was intramuscular $(87.5 \%$ of the cases in dogs). Table 2 also shows that the same doses per $\mathrm{kg}$ body weight were used in small and large dogs.

With the doses chosen, almost all animals were recumbert and $72 \%$ of the dogs, and $85 \%$ of the cats were in a slight anaesthetic stage, unable to rise. Recumbent but able to get up easily were $1.3 \%$ of cases in dogs and $2.4 \%$ in cats. Only few dogs $(0.2 \%)$ and no cats remained standing after the sedation. Half of the dogs showed no reaction to sound, $85 \%$ of all cats had ceased to react to sounds. The duration of sedation was mostly 1-2 $\mathrm{h}$ and with higher doses more than $2 \mathrm{~h}$. The evaluation of the sedative effect of medetomidine in phase $I$ resulted in rating "good" in $76 \%$ of cases or "moderate $"$ in $22 \%$ when the dose in dogs was $30-70 \mu \mathrm{g} / \mathrm{kg}$.
In cats the degree of sedation was good in $75 \%$ of cases at doses $70-110 \mu \mathrm{g} / \mathrm{kg}$ and $83 \%$ when the dose was $110-150 \mu \mathrm{g} / \mathrm{kg}$.

Dogs showed no reaction to pain in pinprick test in $50-60 \%$ of all cases, and cats in $20 \%$. The analgesic effect was rated "good" or "moderate $\ll$ in $75-85 \%$ in dogs and $16 \%$ in cats.

The evaluation of the overall suitability of medetomidine in different indications and weight groups is presented in Table 3 . As shown, the level of satisfaction with the dose selected increased with body weight. Consequently, less favourable ratings were given in small breeds.

The side effects reported in the course of the study are listed in Table 4 . The most prominent side effect was vomiting. It was seen in $10-12 \%$ of the dogs and in $50-65 \%$ of the cats. Heart rate decreased in a dose-related manner to about $50 \%$ from the basic values

Table 3. Evaluation of the overall suitability of medetomidine ( $\%$ of cases) by indications in dogs and cats and by weight groups in dogs.

\begin{tabular}{|c|c|c|c|c|c|c|}
\hline \multirow{3}{*}{$\begin{array}{l}\text { Indications/weight- } \\
\text { groups }\end{array}$} & \multicolumn{6}{|c|}{ Suitability ( $\%$ of cases) } \\
\hline & \multicolumn{2}{|c|}{$\begin{array}{c}\text { very satis- } \\
\text { factory } \\
\text { phase }\end{array}$} & \multicolumn{2}{|c|}{$\begin{array}{l}\text { satis- } \\
\text { factory } \\
\text { phase }\end{array}$} & \multicolumn{2}{|c|}{$\begin{array}{l}\text { unsatis- } \\
\text { factory } \\
\text { phase }\end{array}$} \\
\hline & I & II & I & II & I & II \\
\hline $\begin{array}{l}\text { Indications } \\
\text { Dog: } \\
\text { Examinations, } \\
\text { clinical procedures } \\
\text { Minor operations } \\
\text { Radiography }\end{array}$ & $\begin{array}{l}91.7 \\
92.9 \\
93.5\end{array}$ & $\begin{array}{l}80.6 \\
88.9 \\
92.4\end{array}$ & $\begin{array}{l}7.8 \\
6.1 \\
5.2\end{array}$ & $\begin{array}{r}15.4 \\
8.1 \\
5.1\end{array}$ & $\begin{array}{l}0.5 \\
1.0 \\
1.3\end{array}$ & $\begin{array}{l}4.5 \\
3.0 \\
2.5\end{array}$ \\
\hline $\begin{array}{l}\text { Cat: } \\
\text { Examinations, } \\
\text { clinical procedures } \\
\text { Minor operations } \\
\text { Radiography }\end{array}$ & $\begin{array}{r}66.7 \\
91.5 \\
100.0\end{array}$ & $\begin{array}{r}79.9 \\
100.0 \\
88.9\end{array}$ & $\begin{array}{c}14.3 \\
5.1 \\
0\end{array}$ & $\begin{array}{c}17.6 \\
0 \\
11.9\end{array}$ & $\begin{array}{c}19.0 \\
3.4 \\
0\end{array}$ & $\begin{array}{l}2.8 \\
0 \\
0\end{array}$ \\
\hline $\begin{array}{l}\text { Weight } \\
\text { Dog: } \\
1-5 \mathrm{~kg} \\
6-10 \mathrm{~kg} \\
11-20 \mathrm{~kg} \\
21-30 \mathrm{~kg} \\
30-\quad \mathrm{kg}\end{array}$ & $\begin{array}{l}82.4 \\
90.3 \\
89.9 \\
90.8 \\
93.3\end{array}$ & $\begin{array}{l}80.9 \\
83.0 \\
89.5 \\
91.3 \\
90.0\end{array}$ & $\begin{array}{r}14.7 \\
9.7 \\
8.8 \\
6.7 \\
5.7\end{array}$ & $\begin{array}{r}8.7 \\
12.4 \\
6.7 \\
6.3 \\
8.0\end{array}$ & $\begin{array}{l}2.9 \\
0 \\
1.3 \\
2.5 \\
1.0\end{array}$ & $\begin{array}{r}10.4 \\
4.6 \\
3.8 \\
2.2 \\
1.9\end{array}$ \\
\hline
\end{tabular}


Table 4. Side-effects of medetomidine in dogs and cats.

\begin{tabular}{|c|c|c|c|c|c|c|c|c|}
\hline \multirow[t]{3}{*}{ Side-effect } & \multicolumn{4}{|c|}{ Dog } & \multicolumn{4}{|c|}{ Cat } \\
\hline & \multicolumn{2}{|c|}{ phase I } & \multicolumn{2}{|c|}{ phase II } & \multicolumn{2}{|c|}{ phase I } & \multicolumn{2}{|c|}{ phase II } \\
\hline & cases & $\%$ & cases & $\%$ & cases & $\%$ & cases & $\%$ \\
\hline Vomiting & 76 & 14.3 & 101 & 8.4 & 117 & 65 & 196 & 39.4 \\
\hline Muscle jerking & 11 & 2.1 & 3 & 0.2 & & & 1 & 0.2 \\
\hline Cyanotic mucous membranes & 7 & 1.3 & 2 & 0.2 & & & & \\
\hline Irregular breathing & 7 & 1.3 & 3 & 0.2 & & & & \\
\hline Squealing at injection & 3 & 0.6 & & & 1 & 0.6 & & \\
\hline Diarrhea & 1 & 0.2 & & & 1 & 0.6 & & \\
\hline Panting & & & 2 & 0.2 & & & & \\
\hline Restlessness & & & 1 & 0.1 & & & & \\
\hline Collapse & 1 & 0.2 & & & & & & \\
\hline
\end{tabular}

in 15-30 min and returned slowly back to normal within $1 \mathrm{~h}$.

Two of the dogs, one with warfaring poisoning, the other 11 years old, died 12 and $48 \mathrm{~h}$ after medetomidine sedation and clinical procedure. A third, very aggressive dog with nephritis, gastritis and liver degeneration died $2 \mathrm{~h}$ after the sedation.

The concomitant use of medetomidine and ketamine in cats provided a good anaesthesia for surgery, lasting $20-40 \mathrm{~min}$. The recovery was smooth without any excitatory phase.

\section{Discussion}

The results of the present study show that medetomidine provides an effective level of sedation and analgesia for clinical use. Evaluation of the overall suitability of medetomidine used in different indications was satisfactory or very satisfactory in $95 \%$ of the cases in dogs and $81-96 \%$ in cats, respectively. Mean doses decreased during the study which may explain the fact that the clinicians' satisfaction with the effect of medetomidine was not as good in phase II as in phase I of the study.

It was also found that in small dogs $(<5 \mathrm{~kg})$ the overall suitability was rated "unsatisfactory « more often than in other weight groups. This may be due to the fact that the mean dosage $(\mu \mathrm{g} / \mathrm{kg} \mathrm{BW})$ of medetomidine was similar irrespective of the weight of the animal. Thus, to get an equal effect, higher doses per $\mathrm{kg}$ body weight probably have to be used in small dogs compared to large dogs. The higher dose needed in cats, compared to the dose for dogs, may also in part be due to the lesser weight of the cats, and thus does not indicate real difference in drug response between species. In addition, the cat is usually considered a difficult animal at the veterinarian's clinics, which could have influenced the evaluation of the dose in this study.

Vainio et al. (1989) demonstrated in laboratory beagles, that during the first $\mathrm{h}$ the dogs lay down and were unable to rise at the dose $90 \mu \mathrm{g} / \mathrm{kg}$ i.m. At $30 \mu \mathrm{g} / \mathrm{kg}$ of medetomidine they lay down but rose with difficulty. At the dose $10 \mu \mathrm{g} / \mathrm{kg}$ the dogs lay down but were able to get up easily. Response threshold to electrical stimuli increased significantly at doses 30 and $90 \mu \mathrm{g} / \mathrm{kg}$ of medetomidine (Vainio et al. 1989). The method used in this study allowing the clinicians a free choice of the dose, gave almost the same results for the optimal clinical dose as were obtained in the study above.

The duration of the analgesic effect of xylazine has been stated to last 15 to $30 \mathrm{~min}$, the sedative effect $1-2 \mathrm{~h}$ and up to $3 \mathrm{~h}$ after injec- 
tion (Moye et al. 1973, Newkirk \& Miles 1974).

Side effects reported were limited almost exclusively to vomiting and muscle jerking in dogs and to vomiting in cats. Vomiting occurred especially when medetomidine was used intramuscularly or subcutaneously in $12 \%$ of the cases in dogs and $65 \%$ in cats. However, most investigators regarded vomiting more as an advantage than a disadvantage. Xylazine, as an $\alpha_{2}$-adrenoceptor agonist, causes also vomiting in dogs and cats (Newkirk \& Miles 1974, Amend \& Klavano, 1973). In cats, xylazine has been reported to be a useful emetic (Gräf et al. 1979). The mechanism of the emetic action of xylazine is thought to be mediated through its activation of $\alpha_{2}$-adrenoceptors, most likely in the emetic chemoreceptor zone of the area postrema (Colby et al. 1981, Hikasa et al. 1987). Muscle jerking was found in $0.2-2 \%$ of the cases in dogs and in one cat only. Other side effects reported are infrequent and accidental.

Regarding the 3 animals lost in these studies, the direct cause of death, whether attributable to medetomidine or not, remained unresolved. The severity of symptoms of diseases these dogs suffered from was not reported during the study but became known in posttrial interviews.

\section{Conclusions}

The results obtained in the present study with a large number of animals show that medetomidine produces a reliable state of sedation and analgesia in dogs and cats where clinical examinations, procedures and small surgical operations can be carried out. The optimal dosage of medetomidine in clinical practice seems to be $30-40 \mu \mathrm{g} / \mathrm{kg}$ for dogs and $80-110 \mu \mathrm{g} / \mathrm{kg}$ for cats. Thus for pharmacological restraint of dogs and cats, medetomidine alone seems to suffice, and no combinations with other agents are needed.

\section{Acknowledgements}

The author thanks the Finnish group of clinicians for gathering the clinical material: P. Axelson, I. Happonen, T. \& T. Illukka, M. Jaakkola, H. Jalanka, J. Jussila, O. Laitinen, J. Mårtenson, H. Nurmi, L. Palmu, T. Palolahti, M. Roos, M. Räihä, E. Sarkiala, K. Sittnikow, K. Skutnabb, T. Talvio, T.-R. Vuorikoski, E. Westermarck.

\section{References}

Amend, $J F$ and Klavano, PA: Xylazine: A new sedative-analgesic with predictable emetic properties in the cat. Vet. Med./Small Animal Clin. 1973, 68, 741-742.

Colby, ED, McCarthy, LE and Borison, HL: Emetic action of xylazine on the chemoreceptor trigger zone for vomiting in cats. J. Vet. Pharmacol. Therap. 1981, 4, 93-96.

Gräf, $R, K r a f t, W$ and Ackermann, $U$ : Emetica bei der Katze (Emetics in the cat). Kleintier-Praxis 1979, 24, 371-373.

Hikasa, Y, Takase, $K$, Osada, $T$, Takamatsu, $H$ and Ogasawara, S: Xylazine-induced vomiting in dogs: Elimination by ablation of the area Postrema and blockade by yohimbine. J. Vet. Med. A, 1987, 34, 154-158.

Karjalainen, A: On the design and synthesis of antihypertensive 4(5)-substituted imidazole derivates. Acta Univ. Oul. A125 Chem. 15, Oulu, 1981.

Melby Jr., EC: The Veterinary profession: Changes and challanges. Cornell Vet. 1985, 75, 16-26.

Moye, RJ, Pailet, $A$ and Smith, MW: Clinical use of xylazine in dogs and cats. Vet. Med./Small Anim. Clin. 1973, 68, 236-241.

Newkirk, $H L$ and Miles, DG: Xylazine as a sedativeanalgesic for dogs and cats. Mod. Vet. Pract. 1974, 55, 677-680.

Savola, J-M, Ruskoaho, H, Puurunen, J, Salonen, $J S$ and Kärki NT: Evidence for medetomidine as a selective and potent agonist at alpha-2-adrenoceptors. J. Auton. Pharmacol. 1986, 5, 275-284.

Stenberg, $D$, Salven, $P$ and Miettinen, MVJ: Sedative action of the $\alpha_{2}$-agonist medetomidine in cats. J. Vet. Pharmacol. Therap. 1987, 10, 319-323.

Taylor, PM and Herrtage, ME: Evaluation of some drug combinations for sedation in the dog. $\mathbf{J}$. Small Anim. Pract. 1986, 27, 325-333. 
Vainio, $O$, Vähä-Vahe, $T$ and Palmu, L: Sedative and analgesic effect of medetomidine in dogs. $J$. Vet. Pharmacol. Therap. 1989, 12, 225-231.

Virtanen, $R$ : Detomidine and MPV-785, two sedative/analgesic imidazole derivates with different species selectivity. Abstract, 3rd Congress of the European Association for Veterinary Pharmacology and Toxicology. Aug. 25-29, 1985, Ghent, Belgium, p. 39.

Virtanen, $R$, Savola, J-M, Saano, V, Nyman, L: Characterization of the selectivity, specificity and potency of medetomidine as an alpha-2adrenoceptor agonist. Eur. J. Pharmacol. 1988, 150, 9-14.

\section{Sammenfattning}

Klinisk evaluering av medetomidin, ett nytt sedativum och analgetikum för hundar och katter.

Medetomidin, en effektiv $\boldsymbol{\alpha}_{2}$-adrenoceptor agonist, studerades i öppna, multicentrala kliniska studier med olika hund- och kattraser (1736 hundar och 678 katter) som patienter. Studiens ändamål var att få reda på medetomidins optimala dos för sedering och analgesi i klinisk användning och att utreda hur bra den ämnade undersökningen kunde utföras under påverkan av läkemedlet.

Medetomidins medeldosering (i.m.) vid undersökningar, kliniska procedurer och små kirurgiska ingrepp var $40 \mu \mathrm{g} / \mathrm{kg}$, och vid radiografi $30 \mu \mathrm{g} / \mathrm{kg}$. Hos katt var dosen $80-110 \mu \mathrm{g} / \mathrm{kg}$. Med de valda doserna var nästan alla djur i liggande ställning, och $72 \%$ av hundarna och $85 \%$ av katterna var under mild anestesi och kunde inte stiga upp. Medetomidins allmänna lämplighet $\mathrm{i}$ olika indikationer $(\% \mathrm{av}$ fall) evaluerades som »mycket lämplig« eller »lämplig « i $95 \%$ av hundarna och $80-96 \%$ av katterna.

Rapporterade biverkningar bestod i allmänhet endast av uppkastningar och muskelkramper (12\% och $0,5 \%$ av fallen) samt av uppkastningar hos katt $(65 \%)$. Medetomidin verkar vara en lämplig farmakologisk kontroll hos hund och katt. Medetomidin (80-100 $\mu \mathrm{g} / \mathrm{kg}$ ) i kombination med ketamin (7 $\mathrm{mg} / \mathrm{kg}$ ) åstadkom hos katter $(\mathrm{n}=295)$ en lämplig anestesi (20-40 min). Ảterhämtningen skedde lugnt. Denna studie visar att medetomidin åstadkommer en effektiv nivå av sedation och analgesi vid kliniskt bruk.

(Accepted September 14, 1988).

Reprints may be requested from: Tapani Vähä-Vahe, Research Center, Farmos Group Ltd, Box 425, SF-20101, Turku, Finland. 
